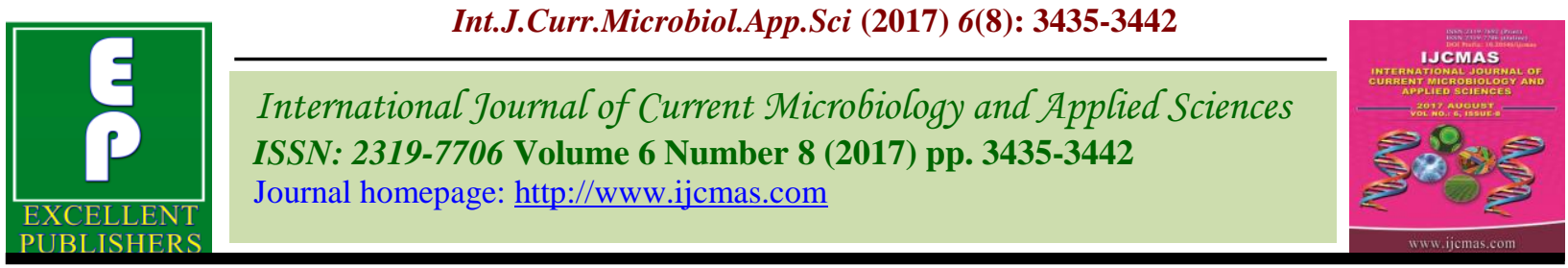

Original Research Article

https://doi.org/10.20546/ijcmas.2017.608.412

\title{
Effect of Different Varieties and Levels of Nitrogen on Growth Functions of Wheat (Triticum aestivum L.)
}

\author{
M. Satyanarayana ${ }^{1 *}$, A. Pratap Kumar Reddy ${ }^{2}$, P. Spandana Bhatt ${ }^{2}$, \\ S. Narender Reddy ${ }^{2}$ and J. Padmaja ${ }^{2}$ \\ ${ }^{1}$ ICRISAT, Hyderabad, Telangana, India \\ ${ }^{2}$ Professor Jayashankar Telangana state agricultural university, Hyderabad, Telangana, India \\ *Corresponding author
}

A B S T R A C T

Keywords

Varieties and levels of nitrogen, Wheat.

Article Info

Accepted:

27 June 2017

Available Online:

10 August 2017
An experiment was conducted during winter season of 2009-10 on sandy clay loam soils of Students' farm, College of Agriculture, Acharya N. G. Ranga Agricultural University, Rajendranagar, Hyderabad to find out the Effect of different varieties and levels of nitrogen on Growth functions wheat (Triticum aestivum L.) The treatments consisted of three varieties (HP 4080, RAJ 4037 and HI 8682) and four nitrogen levels $\left(0,60,120\right.$ and $\left.180 \mathrm{~kg} \mathrm{~N} \mathrm{ha}^{-1}\right)$. The experiment was laid out in randomized block design with varieties as first factor and nitrogen levels as second factor with three replications. The findings of experiment are summarized below. Crop growth rate was maximum between 60-90 DAS and maximum for variety RAJ 4037 and at $180 \mathrm{~kg} \mathrm{~N}^{-1}$ among all the levels of nitrogen. Relative growth rate and net assimilation rates were found maximum between 10-30 days after sowing. Leaf area duration was maximum with RAJ 4037 among the varieties and $180 \mathrm{~kg} \mathrm{~N}^{-1}$ produced higher Leaf area duration. Among the varieties RAJ 4037 produced highest grain yield with $180 \mathrm{~kg} \mathrm{~N} \mathrm{ha}^{-1}$.

\section{Introduction}

Wheat is the most important and widely cultivated food crop in the world. In India, Wheat is the second important cereal crop, first being Rice. In India wheat occupies an area of 28.15 million hectares with a total production of 758.06 million tonnes with an average productivity of $2,708 \mathrm{~kg} \mathrm{ha}{ }^{-1}$. (Source: Ministry of Agriculture, Govt. of India).

In Andhra Pradesh, wheat occupies an area of 10,000 hectares with a total production of 9,000 tonnes with an average productivity of
$900 \mathrm{~kg} \mathrm{ha}^{-1}$ which is very less when compared to the national average productivity. To improve the production of wheat, as in any other crop, introduction of varieties with a high yield potential is essential.

Variety contributes more than 50 percent of the increased production. The next important component for increased production is the nutrient availability. Native fertility level of the tropical soils with special reference to nitrogen is invariably insufficient for touching the peak production mark of a variety and 
hence, the need for supplementing this nutrient is obvious with most varieties.

Productivity of wheat is governed by improved varieties coupled with matching production technology. Suitability of varieties to a particular agro- climate is the most important factor in realizing their yield potential which is further influenced by their response to application of nutrients, particularly nitrogen.

Selection of suitable genotype is of prime importance as the genetic potential of varieties limits response to nitrogen. Moreover, varieties differ both in yield and nutrient uptake.

Hence, it is necessary to find out the correct dose of nitrogen and suitable varieties for maximizing wheat yields in Southern Telangana agro-climatic zone. Therefore, the present study was carried out.

\section{Materials and Methods}

The experiment was conducted during winter seasonon sandy loam soils at students' farm, College of Agriculture, Rajendranagar, Hyderabad which is geographically situated at $17^{0} .19^{1} \mathrm{~N}$ latitude, $78^{0} 28^{1} \mathrm{E}$ longitudes and at an altitude of $542.3 \mathrm{~m}$ above mean sea level, covered under Southern Telangana agroclimatic zone of Andhra Pradesh.

The weekly mean average temperature of $29.7^{\circ} \mathrm{c}$ minimum temperature $15.7^{\circ} \mathrm{c}$. Mean relative humidity ranged from 45 to 82 per cent. The total rain fall received during the crop growth period was $44.8 \mathrm{~mm}$ spread in three rainy days.

The weekly mean sunshine hours varied from 4.4 to 9.1 with an average of 7.66 hours per day and mean evaporation ranged from 4.8 to $7.9 \mathrm{~mm}$ with an average of $6.2 \mathrm{~mm}$ per day.
The mean wind speed ranged from 1.6 to 5.4 $\mathrm{km} \mathrm{hr}{ }^{-1}$ with an average of $3.2 \mathrm{~km} \mathrm{hr}^{-1}$ during the crop growth period

\section{Crop growth rate (CGR): $\left(\mathrm{g} \mathrm{m}^{-2} \mathrm{day}^{-1}\right)$}

Crop growth rate was calculated at the intervals of 10-30 days, 30-60 days, 60-90 days and 90DAS-harvest.

$$
\mathrm{CGR}=\frac{\mathrm{W}_{2}-\mathrm{W}_{1}}{\mathrm{t}_{2}-\mathrm{t}_{1}}
$$

Where,

$\mathrm{W}_{1}=$ Dry weight at time $\mathrm{t}_{1}$

$\mathrm{W}_{2}=$ Dry weight at time $\mathrm{t}_{2}$

Relative growth rate (RGR): $\left(\mathrm{g} \mathrm{g}^{-1} \mathrm{day}^{-1}\right)$

RGR $=\frac{\log _{\mathrm{e}} \mathrm{W}_{2}-\mathrm{Log}_{\mathrm{e}} \mathrm{W}_{1}}{\mathrm{t}_{2}-\mathrm{t}_{1}}$

Where,

$\mathrm{W}_{1}=$ Dry matter at time $\mathrm{t}_{1}$.

$\mathrm{W}_{2}=$ Dry weight at time $\mathrm{t}_{2}$

\section{Net assimilation rate (NAR): $\left(\mathrm{g} \mathrm{dm}^{-2} \mathrm{day}^{-1}\right)$}

Net assimilation rate was calculated at twenty days interval from 10-30 days, and at 30days interval from 30- 60 days after sowing (DAS) and at 90 days after sowing (DAS) to harvesting date.

$$
\mathrm{NAR}=\frac{\left(\mathrm{W}_{2}-\mathrm{W}_{1}\right)\left(\log _{\mathrm{e}} \mathrm{L}_{2}-\log _{\mathrm{e}} \mathrm{L}_{1}\right)}{\left(\mathrm{t}_{2}-\mathrm{t}_{1}\right)\left(\mathrm{L}_{2}-\mathrm{L}_{1}\right)}
$$

Where,

$\mathrm{W}_{1}=$ Dry weight at time $\mathrm{t}_{1}$.

$\mathrm{W}_{2}=$ Dry weight at time $\mathrm{t}_{2}$ 
$\mathrm{L}_{1}=$ Leaf area at time $\mathrm{t}_{1}$.

$\mathrm{L}_{2}=$ Leaf area at time $\mathrm{t}_{2}$.

Leaf Area Duration (LAD): $\left(\mathrm{m}^{2}\right.$ day $\left.^{-1}\right)$

$\mathrm{LAD}=\left(\mathrm{LAI}_{1}+\mathrm{LAI}_{2}\right) \times\left(\mathrm{T}_{2}-\mathrm{T}_{1}\right) / 2$

Where,

$\mathrm{LAI}_{1}=$ Leaf area Index at $\mathrm{t}_{1}$

$\mathrm{LAI}_{2}=$ Leaf area index at $\mathrm{t}_{2}$

\section{Results and Discussion}

\section{Crop growth rate}

Crop growth rate of wheat increased up to 6090DAS and then decreased.

Crop growth rate of wheat was significantly influenced by varieties and nitrogen levels and the interaction effect was found to be significant from 60-90DAS and 90DASharvest.

Among the varieties RAJ 4037 recorded significantly higher CGR at all the growth stages and was on par with $\mathrm{HI} 8682$ at 3060DAS, which in turn was comparable with variety HP 4080 at other stages.

The higher CGR of variety RAJ 4037 can be attributed to rapid accumulation of dry matter compared to other two varieties.

Crop growth rate of wheat was significantly influenced by nitrogen levels at all the growth stages. With increase in nitrogen level from 0 $\mathrm{kg} \mathrm{ha}^{-1}$ to $180 \mathrm{~kg} \mathrm{ha}^{-1}$ CGR also increased significantly. From 90DAS-harvest application of $120 \mathrm{~kg} \mathrm{~N} \mathrm{ha}^{-1}$ and $180 \mathrm{~kg} \mathrm{~N}^{-}$ ${ }^{1}$ recorded on par CGR. The higher dose of nitrogen has led to better accumulation of dry matter, thus the effect is reflected in the form of crop growth rate between different substages.
Interaction studies revealed that at $180 \mathrm{~kg} \mathrm{~N}$ $\mathrm{ha}^{-1}$ all the three varieties recorded on par and maximum CGR from 60-90 DAS. From 90DAS-harvest application of 120 and $180 \mathrm{~kg}$ $\mathrm{N}$ ha ${ }^{-1}$ recorded comparable CGR in RAJ 4037 and HI 8682 and was significantly higher than other variety and other levels of nitrogen.

\section{Relative growth rate}

Relative growth rate of wheat decreased with increase in duration of the crop.

Up to 60 DAS the varieties did not vary significantly in RGR whereas from 60-90 DAS HP 4080 recorded significantly higher RGR over RAJ 4037 and HI 8682 which were on par with each other.

Relative Growth Rate of wheat was significantly influenced by nitrogen levels at all the growth stages. From 10-30 DAS with increase in nitrogen level from $0 \mathrm{~kg} \mathrm{ha}^{-1}$ to $180 \mathrm{~kg} \mathrm{ha}^{-1}$ RGR also increased significantly. From 30-60 DAS, RGR decreased significantly with increase in nitrogen level from $0 \mathrm{~kg} \mathrm{ha}^{-1}$ to $180 \mathrm{~kg} \mathrm{ha}^{-1}$ whereas from 60-90 DAS $0 \mathrm{~kg} \mathrm{ha}^{-1}$ recorded significantly lower RGR compared to other three doses which were on par with each other. From 90DAS-harvset $\mathrm{N}$ application up to $120 \mathrm{~kg} \mathrm{~N}$ $\mathrm{ha}^{-1}$ recorded significantly higher RGR over other three doses which were comparable with each other.

The interaction of varieties and nitrogen levels on RGR was found to be significant at all growth stages except from 30-60DAS. From 10-30DAS highest RGR was recorded at $180 \mathrm{~kg} \mathrm{~N} \mathrm{ha}^{-1}$ by the variety HP 4080 which was found significantly superior to all the other interactions. From 60-90 DAS increase in nitrogen levels from $120 \mathrm{~kg}$ to 180 $\mathrm{kg} \mathrm{ha}^{-1}$ did not increase RGR significantly with HP 4080 whereas RAJ 4037 and HI 
8682 gave significantly higher and comparable RGR with 60 and $120 \mathrm{~kg} \mathrm{~N} \mathrm{ha}^{-1}$.

\section{Net assimilation rate}

Net assimilation rate of wheat decreased with increase in duration of the crop. The net assimilation rate was found highest at 10-30 DAS. Net assimilation rate of wheat was not significantly influenced by varieties at early growth stages whereas from 60-90 DAS highest net assimilation rate was recorded by varieties HP 4080 and RAJ 4037 which were found significantly superior to HI 8682.

Table.1 Crop Growth Rate $\left(\mathrm{g} \mathrm{m}^{-2}\right.$ day $\left.^{-1}\right)$ of wheat as influenced by varieties and nitrogen levels

\begin{tabular}{|l|c|c|c|c|}
\hline Treatment & 10- 30 DAS & 30- 60 DAS & $60-90$ DAS & 90 DAS-harvest \\
\hline Varieties & 5.54 & 4.46 & 6.27 & 4.27 \\
\hline HP 4080 & 5.88 & 4.95 & 6.46 & 4.81 \\
\hline RAJ 4037 & 5.64 & 4.81 & 6.10 & 4.51 \\
\hline $\mathrm{HI} 8682$ & 0.06 & 0.05 & 0.06 & 0.09 \\
\hline S.Em \pm & 0.12 & 0.16 & 0.18 & 0.26 \\
\hline C.D $(\mathrm{P}=0.05)$ & Nitrogen levels \\
\hline 0 kg N ha & \multicolumn{5}{l|}{} \\
\hline $60 \mathrm{~kg} \mathrm{~N} \mathrm{ha}^{-1}$ & 3.15 & 3.73 & 2.61 & 2.50 \\
\hline $120 \mathrm{~kg} \mathrm{~N} \mathrm{ha}^{-1}$ & 4.76 & 4.51 & 6.08 & 3.77 \\
\hline $180 \mathrm{~kg} \mathrm{~N} \mathrm{ha}$ & 6.52 & 5.23 & 7.33 & 6.03 \\
\hline S.Em \pm & 8.32 & 5.49 & 9.09 & 5.83 \\
\hline C.D $(\mathrm{P}=0.05)$ & 0.05 & 0.06 & 0.07 & 0.10 \\
\hline Interaction $(\mathrm{V} \mathrm{X} \mathrm{N)}$ & 0.15 & 0.19 & 0.20 & 0.30 \\
\hline
\end{tabular}

Table.2 Interaction effect of different varieties and nitrogen levels on Crop Growth Rate $\left(\mathrm{g} \mathrm{m}^{-2}\right.$ day $\left.^{-1}\right)$ at 60-90 DAS

\begin{tabular}{|l|l|l|l|l|}
\hline Treatments & \multicolumn{4}{|c|}{ Varieties } \\
\hline & HP 4080 & RAJ 4037 & HI 8682 & Mean \\
\hline Nitrogen levels kg ha $^{-1}$ & 2.71 & 2.66 & 2.45 & 2.61 \\
\hline $0 \mathrm{~kg} \mathrm{~N} \mathrm{~h}^{-1}$ & 5.71 & 6.50 & 6.04 & 6.08 \\
\hline $60 \mathrm{~kg} \mathrm{~N} \mathrm{~h}^{-1}$ & 7.47 & 7.51 & 7.00 & 7.33 \\
\hline $120 \mathrm{~kg} \mathrm{~N} \mathrm{~h}^{-1}$ & 9.20 & 9.15 & 8.91 & 9.09 \\
\hline $180 \mathrm{~kg} \mathrm{~N} \mathrm{~h}$ & \\
\hline Mean & 6.27 & 6.46 & 6.10 & \\
\hline S.Em \pm & $\mathbf{0 . 1 2}$ \\
C.D $(\mathbf{P}=\mathbf{0 . 0 5})$ & $\mathbf{0 . 3 6}$ & \multicolumn{5}{|l}{} \\
\hline
\end{tabular}

Table.3 Interaction effect of different varieties and nitrogen levels on Crop Growth Rate $\left(\mathrm{g} \mathrm{m}^{-2}\right.$ day $\left.^{-1}\right)$ at 90DAS-Harvest

\begin{tabular}{|l|l|l|l|l|}
\hline Treatments & \multicolumn{4}{|c|}{ Varieties } \\
\hline & HP 4080 & RAJ 4037 & HI 8682 & Mean \\
\hline Nitrogen levels kg ha $^{-1}$ & 1.88 & 2.93 & 2.67 & 2.50 \\
\hline $0 \mathrm{~kg} \mathrm{~N} \mathrm{ha}^{-1}$ & 4.33 & 3.67 & 3.30 & 3.77 \\
\hline $60 \mathrm{~kg} \mathrm{~N} \mathrm{ha}^{-1}$ & 5.53 & 6.33 & 6.25 & 6.03 \\
\hline $120 \mathrm{~kg} \mathrm{~N} \mathrm{ha}^{-1}$ & 5.33 & 6.31 & 5.84 & 5.83 \\
\hline $180 \mathrm{~kg} \mathrm{~N} \mathrm{ha}^{-1}$ & 4.27 & 4.81 & 4.51 & \\
\hline Mean & $\mathbf{0 . 1 8}$ & \multicolumn{5}{|l}{} \\
\hline S.Em \pm & $\mathbf{0 . 5 2}$ & \multicolumn{5}{|l}{$(\mathbf{P}=\mathbf{0 . 0 5})$} &
\end{tabular}


Table.4 Relative growth rate $\left(\mathrm{g} \mathrm{g}^{-1} \mathrm{day}^{-1}\right)$ of wheat as influenced by varieties and nitrogen levels

\begin{tabular}{|c|c|c|c|c|}
\hline Treatment & 10-30 DAS & 30-60 DAS & 60-90 DAS & 90DAS-Hrvest \\
\hline \multicolumn{5}{|l|}{ Varieties } \\
\hline HP 4080 & 0.111 & 0.026 & 0.018 & 0.008 \\
\hline RAJ 4037 & 0.112 & 0.026 & 0.017 & 0.009 \\
\hline HI 8682 & 0.111 & 0.026 & 0.017 & 0.009 \\
\hline S.Em \pm & 0.001 & 0.001 & 0.0002 & 0.0002 \\
\hline C.D $(\mathrm{P}=0.05)$ & N.S & N.S & 0.0006 & N.S \\
\hline \multicolumn{5}{|l|}{ Nitrogen levels } \\
\hline $0 \mathrm{~kg} \mathrm{~N} \mathrm{ha}^{-1}$ & 0.097 & 0.031 & 0.012 & 0.008 \\
\hline $60 \mathrm{~kg} \mathrm{~N} \mathrm{ha}^{-1}$ & 0.108 & 0.027 & 0.019 & 0.008 \\
\hline $120 \mathrm{~kg} \mathrm{~N} \mathrm{ha}^{-1}$ & 0.118 & 0.025 & 0.018 & 0.010 \\
\hline $180 \mathrm{~kg} \mathrm{~N} \mathrm{ha}^{-1}$ & 0.123 & 0.021 & 0.019 & 0.008 \\
\hline S.Em \pm & 0.0005 & 0.0003 & 0.0003 & 0.0002 \\
\hline C.D $(\mathrm{P}=0.05)$ & 0.0014 & 0.001 & 0.0008 & 0.0007 \\
\hline Interaction $(\mathrm{V} \mathrm{X} \mathrm{N})$ & 0.003 & N.S & 0.001 & 0.001 \\
\hline
\end{tabular}

Table.5 Interaction effect of different varieties and nitrogen levels on RGR ( g g$^{-1}$ day $\left.^{-1}\right)$ at 10-30 DAS

\begin{tabular}{|l|l|l|l|l|}
\hline Treatments & \multicolumn{5}{|c|}{ Varieties } \\
\hline & HP 4080 & RAJ 4037 & HI 8682 & Mean \\
\hline Nitrogen levels kg ha & -1 \\
\hline $0 \mathrm{~kg} \mathrm{~N} \mathrm{ha}^{-1}$ & 0.094 & 0.101 & 0.097 & 0.097 \\
\hline $60 \mathrm{~kg} \mathrm{~N} \mathrm{ha}^{-1}$ & 0.109 & 0.107 & 0.107 & 0.108 \\
\hline $120 \mathrm{~kg} \mathrm{~N} \mathrm{ha}^{-1}$ & 0.117 & 0.120 & 0.119 & 0.118 \\
\hline $180 \mathrm{~kg} \mathrm{~N} \mathrm{ha}^{-1}$ & 0.126 & 0.122 & 0.121 & 0.123 \\
\hline Mean & 0.111 & 0.112 & 0.111 & -- \\
\hline S.Em $\mathbf{E}$ & $\mathbf{0 . 0 0 1}$ & & \\
C.D $(\mathbf{P}=\mathbf{0 . 0 5})$ & $\mathbf{0 . 0 0 3}$ & & \\
\hline
\end{tabular}

Table.6 Interaction effect of different varieties and nitrogen levels on RGR ( $\mathrm{g} \mathrm{g}^{-1}$ day $\left.^{-1}\right)$ at 60-90 DAS

\begin{tabular}{|l|l|l|l|l|}
\hline Treatments & \multicolumn{4}{|c|}{ Varieties } \\
\hline & HP 4080 & RAJ 4037 & HI 8682 & Mean \\
\hline Nitrogen levels kg ha & -1 \\
\hline $0 \mathrm{~kg} \mathrm{~N} \mathrm{ha}^{-1}$ & 0.013 & 0.011 & 0.011 & 0.012 \\
\hline $60 \mathrm{~kg} \mathrm{~N} \mathrm{ha}^{-1}$ & 0.018 & 0.019 & 0.019 & 0.019 \\
\hline $120 \mathrm{~kg} \mathrm{~N} \mathrm{ha}^{-1}$ & 0.020 & 0.018 & 0.017 & 0.018 \\
\hline $180 \mathrm{~kg} \mathrm{~N} \mathrm{ha}^{-1}$ & 0.020 & 0.019 & 0.019 & 0.019 \\
\hline Mean & 0.018 & 0.017 & 0.017 & \\
\hline S.Em \pm & $\mathbf{0 . 0 0 5}$ & & \\
C.D $(\mathbf{P}=\mathbf{0 . 0 5})$ & $\mathbf{0 . 0 0 1}$ & & \\
\hline
\end{tabular}


Table.7 Interaction effect of different varieties and nitrogen levels on RGR ( $\mathrm{g} \mathrm{g}^{-1}$ day $\left.^{-1}\right)$ at 90 DAS-harvest

\begin{tabular}{|c|c|c|c|c|}
\hline \multirow[t]{2}{*}{ Treatments } & \multicolumn{4}{|c|}{ Varieties } \\
\hline & HP 4080 & RAJ 4037 & HI 8682 & Mean \\
\hline \multicolumn{5}{|c|}{ Nitrogen levels $\mathrm{kg} \mathrm{ha}^{-1}$} \\
\hline $0 \mathrm{~kg} \mathrm{~N} \mathrm{ha}^{-1}$ & 0.007 & 0.009 & 0.009 & 0.008 \\
\hline $60 \mathrm{~kg} \mathrm{~N} \mathrm{ha}^{-1}$ & 0.009 & 0.008 & 0.007 & 0.008 \\
\hline $120 \mathrm{~kg} \mathrm{~N} \mathrm{ha}^{-1}$ & 0.009 & 0.010 & 0.010 & 0.010 \\
\hline $180 \mathrm{~kg} \mathrm{~N} \mathrm{ha}^{-1}$ & 0.008 & 0.009 & 0.008 & 0.008 \\
\hline Mean & 0.008 & 0.009 & 0.009 & --- \\
\hline $\begin{array}{l}\text { S.Em } \pm \\
\text { C.D }(P=0.05)\end{array}$ & $\begin{array}{l}0.005 \\
0.001\end{array}$ & & & \\
\hline
\end{tabular}

Table.8 Leaf area duration $\left(\mathrm{m}^{2} \mathrm{day}^{-1}\right)$ of wheat as influenced by varieties and nitrogen level

\begin{tabular}{|l|c|c|c|}
\hline Treatment & 10-30 DAS & 30-60 DAS & 60-90 DAS \\
\hline Varieties & 15.00 & 57.30 & 59.85 \\
\hline HP 4080 & 16.21 & 61.76 & 64.97 \\
\hline RAJ 4037 & 15.68 & 59.60 & 62.60 \\
\hline HI 8682 & 0.09 & 0.24 & 0.37 \\
\hline S.Em \pm & 0.26 & 0.70 & 1.08 \\
\hline C.D $(\mathrm{P}=0.05)$ & Nitrogen levels & 33.75 & 37.07 \\
\hline $0 \mathrm{~kg} \mathrm{~N} \mathrm{ha}^{-1}$ & 8.40 & 55.41 & 59.83 \\
\hline $60 \mathrm{~kg} \mathrm{~N} \mathrm{ha}^{-1}$ & 13.97 & 69.88 & 73.03 \\
\hline $120 \mathrm{~kg} \mathrm{~N} \mathrm{ha}^{-1}$ & 18.04 & 79.16 & 80.01 \\
\hline $180 \mathrm{~kg} \mathrm{~N} \mathrm{ha}$ & -1 & 0.27 & 0.42 \\
\hline S.Em \pm & 22.12 & 0.81 & 1.25 \\
\hline C.D $(\mathrm{P}=0.05)$ & 0.10 & N.S & N.S \\
\hline Interaction $(\mathrm{V} \mathrm{X} \mathrm{N)}$ & 0.30 & N.S &
\end{tabular}

Table.9 Net Assimilation Rate $\left(\mathrm{g} \mathrm{dm}^{-2} \mathrm{day}^{-1}\right)$ of wheat as influenced by Varieties and nitrogen levels

\begin{tabular}{|c|c|c|c|}
\hline Treatment & 10-30 DAS & 30-60 DAS & 60-90 DAS \\
\hline \multicolumn{4}{|l|}{ Varieties } \\
\hline HP 4080 & 0.087 & 0.026 & 0.031 \\
\hline RAJ 4037 & 0.084 & 0.027 & 0.030 \\
\hline HI 8682 & 0.085 & 0.027 & 0.029 \\
\hline S.Em \pm & 0.001 & 0.001 & 0.0004 \\
\hline C.D $(P=0.05)$ & N.S & N.S & 0.0010 \\
\hline \multicolumn{4}{|l|}{ Nitrogen levels } \\
\hline $0 \mathrm{~kg} \mathrm{~N} \mathrm{ha}^{-1}$ & 0.084 & 0.035 & 0.022 \\
\hline $60 \mathrm{~kg} \mathrm{~N} \mathrm{ha}^{-1}$ & 0.082 & 0.026 & 0.031 \\
\hline $120 \mathrm{~kg} \mathrm{~N} \mathrm{ha}^{-1}$ & 0.085 & 0.024 & 0.031 \\
\hline $180 \mathrm{~kg} \mathrm{~N} \mathrm{ha}^{-1}$ & 0.090 & 0.022 & 0.035 \\
\hline S.Em \pm & 0.001 & 0.0005 & 0.0004 \\
\hline C.D $(\mathrm{P}=0.05)$ & 0.003 & 0.0015 & 0.0012 \\
\hline Interaction $(\mathrm{V} \mathrm{X} \mathrm{N})$ & N.S & N.S & 0.002 \\
\hline
\end{tabular}


Table.10 Interaction effect of different varieties and nitrogen levels on Net Assimilation Rate $\left(\mathrm{g} \mathrm{dm}^{-2}\right.$ day $\left.^{-1}\right)$ at 60-90 DAS

\begin{tabular}{|l|l|l|l|l|}
\hline Treatments & \multicolumn{5}{|c|}{ Varieties } \\
\hline & HP 4080 & RAJ 4037 & HI 8682 & Mean \\
\hline Nitrogen levels kg ha-1 & \multicolumn{1}{|c|}{} \\
\hline $0 \mathrm{~kg} \mathrm{~N} \mathrm{ha}^{-1}$ & 0.025 & 0.021 & 0.021 & 0.022 \\
\hline $60 \mathrm{~kg} \mathrm{~N} \mathrm{ha}^{-1}$ & 0.030 & 0.032 & 0.031 & 0.031 \\
\hline $120 \mathrm{~kg} \mathrm{~N} \mathrm{ha}^{-1}$ & 0.033 & 0.031 & 0.030 & 0.031 \\
\hline $180 \mathrm{~kg} \mathrm{~N} \mathrm{ha}^{-1}$ & 0.037 & 0.034 & 0.034 & 0.035 \\
\hline Mean & 0.031 & 0.030 & 0.029 & \\
\hline S.Em $\mathbf{E}$ & $\mathbf{0 . 0 0 1}$ & & \\
C.D $(\mathbf{P}=\mathbf{0 . 0 5})$ & $\mathbf{0 . 0 0 2}$ & & \\
\hline
\end{tabular}

Table.11 Grain yield $\left(\mathrm{kg} \mathrm{ha}^{-1}\right)$, Straw yield $\left(\mathrm{kg} \mathrm{ha}^{-1}\right)$ and Harvest Index (\%) of wheat as influenced by varieties and nitrogen levels

\begin{tabular}{|c|c|}
\hline Treatment & Grain yield $\left(\mathrm{kg} \mathrm{ha}^{-1}\right)$ \\
\hline \multicolumn{2}{|l|}{ Varieties } \\
\hline HP 4080 & 2660.41 \\
\hline RAJ 4037 & 2930.00 \\
\hline HI 8682 & 2784.16 \\
\hline S.Em \pm & 10.86 \\
\hline C.D $(\mathrm{P}=0.05)$ & 31.85 \\
\hline \multicolumn{2}{|l|}{ Nitrogen level } \\
\hline $0 \mathrm{~kg} \mathrm{~N} \mathrm{ha}^{-1}$ & 1506.66 \\
\hline $60 \mathrm{~kg} \mathrm{~N} \mathrm{ha}^{-1}$ & 2513.00 \\
\hline $120 \mathrm{~kg} \mathrm{~N} \mathrm{ha}^{-1}$ & 3324.44 \\
\hline $180 \mathrm{~kg} \mathrm{~N} \mathrm{ha}^{-1}$ & 3821.11 \\
\hline S.Em \pm & 12.55 \\
\hline C.D $(\mathrm{P}=0.05)$ & 36.81 \\
\hline Interaction $(\mathrm{V} \mathrm{X} \mathrm{N})$ & 63.77 \\
\hline
\end{tabular}

Net assimilation rate of wheat was significantly influenced by nitrogen levels at all the growth stages. With increase in nitrogen level from 0 $\mathrm{kg} \mathrm{ha}{ }^{-1}$ to $180 \mathrm{~kg} \mathrm{ha}^{-1}$ NAR also increased significantly except from 30-60 DAS, where, NAR decreased significantly with increase in nitrogen level from $0 \mathrm{~kg} \mathrm{ha}^{-1}$ to $180 \mathrm{~kg} \mathrm{ha}^{-1}$.

The interaction effect of varieties and nitrogen levels was found to be significant from 6090DAS. From 60-90DAS the NAR was found maximum with HP 4080 at $180 \mathrm{~kg} \mathrm{~N}^{-1}$ which was significantly superior over all the other interaction effects.

\section{Leaf area duration}

Leaf area duration of wheat was significantly influenced by varieties and nitrogen levels. The interaction of varieties and nitrogen levels on leaf area duration was found non-significant.

Among the varieties RAJ 4037 recorded significantly higher leaf area duration followed by HI 8682 and HP 4080 at all growth stages.

With increase in nitrogen level from $0 \mathrm{~kg} \mathrm{ha}^{-1}$ to $180 \mathrm{~kg} \mathrm{ha}^{-1}$ LAD also increased significantly upto180 $\mathrm{kg} \mathrm{N} \mathrm{ha}{ }^{-1}$. These results were in conformity with the findings of A. Srinivas (2002). For varieties and nitrogen levels LAD 
increased rapidly up to 60 DAS and there after increase was marginal. This might be due to the decrease in leaf area index at 90 DAS.

\section{Grain yield}

The grain yield of wheat was significantly influenced by varieties and nitrogen levels. The variety RAJ 4037 recorded the highest grain yield $\left(2930 \mathrm{~kg} \mathrm{ha}^{-1}\right)$ which was significantly superior to the other two varieties tested. The results were in conformity with Parihar and Tiwari (2003), Behara and Pradhan (2007) and Sharma and Ashok Kumar (2009).

Increasing the nitrogen level from $0 \mathrm{~kg} \mathrm{ha}^{-1}$ to $180 \mathrm{~kg} \mathrm{ha}^{-1}$ significantly increased the grain yield from $1506.66 \mathrm{~kg} \mathrm{ha}^{-1}$ to $3821.11 \mathrm{~kg} \mathrm{ha}^{-1}$. The increase in grain yield with enhanced $\mathrm{N}$ levels can be ascribed to better plant growth and dry matter production due to higher photosynthetic area. The results were in corroboration with findings of Sharma and Manohar (2002) that increase in yield was up to $120 \mathrm{~kg} \mathrm{~N} \mathrm{ha}^{-1}$

The interaction effect studies of grain yield has shown that highest grain yield (4033.00 kg ha-1) was obtained at $180 \mathrm{~kg} \mathrm{~N}^{-1}$ with the variety RAJ 4037 which was significantly higher than HI 8682 and HP 4080. Among the three varieties RAJ 4037 proved to be the best variety in terms of Crop growth rate and Leaf area duration which in turn led to higher grain yield when compared to the other two varieties HP 4080 and HI 8682. Net assimilation rate was not significantly influenced at early stages, whereas from 60-90 DAS highest net assimilation rate was recorded by varieties HP 4080 and RAJ 4037 which were found significantly superior to HI 8682. Among the nitrogen levels $180 \mathrm{~kg} \mathrm{ha}$ ${ }^{1}$ has produced higher Crop growth rate, Leaf area duration. Net assimilation rate also followed the same trend except at 30-60 days after sowing. The increase in Crop growth rate, Dry matter accumulation, Net assimilation rate and Leaf area duration led to higher grain yield at $180 \mathrm{~kg} \mathrm{~N}^{-1}$.Among the three varieties RAJ 4037 has proved to be the best variety and 180 $\mathrm{kg} \mathrm{Nha}{ }^{-1}$ produced the maximum in terms of grain yield.

As the grain yield has shown the increasing trend from $0 \mathrm{~kg} \mathrm{~N} \mathrm{ha}^{-1}$ to $180 \mathrm{~kg} \mathrm{~N}^{-1}$, further study may be carried out with higher levels of nitrogen.

\section{References}

Behera, U.K., and Pradhan, S. 2007. Performance of very late sown bread wheat cultivation as influenced by different level of nitrogen in the vertisols of central India. Annals if Agriculture Research.20 (2):127-131.

Parihar, S.S., and Tiwari, R.B. 2003. Effect of irrigation and nitrogen levels on yield, nutrient uptake and water use of latesown wheat (Triticum aestivum). Indian Journal of Agronomy 48(2): 103-107

Sharma, K.D., and Ashok Kumar 2009. Physiological processes associated with grain yield of wheat under restricted soil moisture. Indian Journal of Plant Physiology 14(1): 55-59.

Sharma, P.K., and Manohar, S.S. 2002. Response of wheat (Triticum aestivum L.) to nitrogen and sulphur and their residual effect on pearl millet (Pennisetumglaucum L.). Indian Journal of Agronomy.47 (4):473-476.

Srinivas, A., 2002. Influence of nitrogen and methods of Zinc application on growth and Yield of Wheat (Triticum aestivum) varieties. Indian Journal of Agricultural Research.36 (3):167-171.

\section{How to cite this article:}

Satyanarayana, M., A. Pratap Kumar Reddy, P. Spandana Bhatt, S. Narender Reddy and Padmaja, J. 2017. Effect of Different Varieties and Levels of Nitrogen on Growth Functions of Wheat (Triticum aestivum L.). Int.J.Curr.Microbiol.App.Sci. 6(8): 3435-3442.

doi: https://doi.org/10.20546/ijcmas.2017.608.412 